\title{
Process and Impact of Globalization in Nepalese Women
}

\author{
Manju Sharma
}

\begin{abstract}
This paper explores the impact of globalization in Nepalese women. The changes on the women's way of life due to globalization can be seen directly in the economy, media, IT sectors, various parts of society and ultimately in the culture. When the Nepalese women entered into the globalization process the Hindu norms and values of the society (where more than 82 percent are Hindu) has creolized with the global way of life. The women are becoming more selfreliant and empowered due to globalization but at the same time they are entering more risky markets to fulfill the desires that floated by the globalization. Similarly, globalization has offered various employment opportunities and exposure in international arena, but it also creates mental anxiety, depression and sexual abuse for those remaining in or outside the country. As there is very limited research and study on the impact of globalization in the Nepalese society, it is too early to conclude the impact of globalization as good or bad on Nepalese women.
\end{abstract}

Keywords: Globalization, Culture, Hindu, Women, Norms and Values

\section{Introduction}

Globalization is a borderless concept of interaction and integration of goods, knowledge, services, culture, and people. This process creates interdependence and interconnectedness, therefore it is the most spread out, discussed, and even debatable subject in the 
contemporary world. Cultural Globalization, one of the facets of globalization, refers to "the emergence of a specific set of values and beliefs that are largely shared around the planet" (Castells, 2009, p. 117). From the cultural perspective, the intensification of global interconnectedness entail increased standardization, homogenization and universalization in one hand and in the same time furnishes heterogenization, hybridization, creolization and various forms of resistance and accommodation to unifying desires. To understand the spread of culture, ideologies, and lifestyles around the world, cultural imperialism and cultural hybridization theories have been developed. Cultural imperialism states that some cultures dominate and eventually replace other cultures. This became a popular way to understand the spread of Western culture to the rest of the world. The flow of commodities, advertisement and media has established a new ground for the construction of meaning and the formation of identities. New subjectivities and identities emerge, along with new social imaginaries and cultural repertoires. One the other hand cultural hybridity states that cultures do not just blindly adopt dominant cultural traits, but rather borrow parts of different culture that complement or contribute to their own which also is called cultural creolization.

Therefore, globalization is no more simply a modernizing or westernizing affair rather it is a homogenizing one; different cultural practices blended into one. It, as Fisher 2011) states, must be understood as a complex process that brings the West to the rest and the rest to the West. Further, Inda and Rosaldo (2002) emphasize on reciprocal nature of cultural globalization. Globalization must be understood, in short, as a process of mutual imbrications (Inda and Rosaldo 2002). The impact of globalization on culture may also be seen as a blend of the heterogeneous and homogenous, or a type of "glocalization", mixture of global and local. Glocalization can be understood as a development of hybrid cultures at the local level, as foreign cultures reach local soil, such as in the creation of fusion cuisine or music. On the other hand, Hiebert's worldviews model of cultural transformation states three levels of culture; surface, middle and core. Surface level of culture is visible and everyone can see it, such as cultural products, the pattern of behavior, signs, rituals, and 


\section{0| Manju Sharma}

so forth. Middle level, below the surface level is conscious feelings, beliefs, and values of a culture. One judges good or bad on the basis of belief. The core of culture is implicit which cannot be seen and identified such as worldview, logics, and epistemology (Hiebert 1985 and 2008). In this theoretical discussion by analyzing impact of social media, migration itself and women movements, the paper tries to identify how globalization process is appearing in the culture of Nepalese women and how it is affecting the women's way of life. Therefore, the main objective of the paper is to examine the way of life of Nepalese women due to the influence of globalization. Further the paper also analyses the positive and negative consequences of globalization on the women's way of life.

\section{Theoretical Base}

Culture is derived from the Latin word 'cultura' meaning" to cultivate." It means something cultivated or ripened. In anthropology, culture generally refers to a way of life, or the ideas, habits, norms, values, and behaviors that members of a community transmit from generation to generation. In this sense, culture, as Tylor (1871) defined it more than 140 years ago, "is that complex whole which includes knowledge, belief, art, morals, laws, customs, and any other capabilities and habits acquired by man as a member of a society" (p. 1). Culture is therefore a person as a whole. What a person believes and values, how s/he evaluates and judges, how s/he senses and responses all are a reflection of a culture.

Berger and Luckmann (1966) explain that our understanding of the social world is shared understanding which is created and maintained through daily social interactions and communications. Socially constructed knowledge appears in the form of beliefs, shared values and social norms. Society, as a subjective reality, describes how our conception of reality originates from our interaction with social structures. Those concepts become a part of our reality through the process of objectification of the inventions. When these objective realities are institutionalized, they appear as a form of culture.

In addition, Gergen (2003) states that social reality is not automatically driven by the forces of nature. It is constructed in a 


\section{1| Manju Sharma}

process of understanding, which is the result of an active, cooperative, enterprise of persons in a relationship and it is construed through the historical and cultural bases. In the process of construction, there would be interaction between and/among two or more persons, there would be an object or event that we engage with, there would be persons or ideas that inform us, there would be power over and power resistance.

\section{Traditional Hindu Culture towards Women}

The social concept about Hinduism and women's position in Hindu society is shaped by various religious texts like the Manusmriti (the codes for Hindu); the Chanakya Niti (code of rulers), Sanskrit epics, the Ramayana and the Mahabharata among others. Here are some ideas from some of these influential Hindu scripts that shaped women's position in Nepalese society. The practices, codes, values and belief systems rooted in Hinduism determined the meaning of good and bad, right or wrong, master and subordinate varied in different era.

The Ramayana presented the story of Sita, who, left her palace and chose to stay with her husband in jungle for 14 years, was abducted by Ravana, a demon. When Ram freed her from war he asked Sita to prove her purity through Aagnipariksha (a purity test by jumping onto the fire). Even after being proven pure, Ram exiled Sita to the jungle (Gewali, 1954). The same Sita was portrayed as the most ideal wife for the Hindus (Young, 2002, p. 12).

Primarily, the Puranas and the Manusmriti were influential during the classical and early periods which have set dual positions (Halder \& Jaishankar, 2009). They stated that, in one hand, the Puranas, mythological stories, have described Goddess as Shakti (Goddess of universal power), Mahalaxmi (Goddess of wealth), and Mahasaraswati (Goddess of Knowledge); the husband should provide for his wife's material needs, her security, protection and social status which itself contradicts. On duality, Shah (2004) also argued, "In one hand, power of motherhood is symbolized in a form of creator - mata - on the other hand, they are controlled to protect 
pre-sexual sacredness" (p. 88). The Manusmriti lays down the rules of conduct, the privileges and obligations, penalties and punishments. Regarding to women, women marriage is indissoluble, divorce impossible, and widow remarriage never permitted to "respectable women." The Manusmriti, traditionally the most authoritative book of the Hindu code, talks of three stages of a woman as in childhood a female must be subject to her father, in youth to her husband, when her lord is dead to her sons: a woman must never be independent. The husband should also respect his wife as a goddess. It tells the happiness of wife is a key to the stability of a family. In the one hand it values women by saying where women are honored, there the God become pleased. On the other hand, it places women below the status of Sudra, the lowest strata of Hindu society.

The Pauranic story also portrayed women as the influential subject of sin that certain by creator. Bennett (2002) explained that the concept of purity during menstrual cycle is established by mythical stories that menstrual blood is a source of sin thrown by Creator (Brahma) (pp. 215-216). The Rig Vedic concept of this "purity" is used to confine women's sexuality in Hindu tradition (Chawala, 1992). Therefore, Hindu women are recognized as polluted during menarche and childbirth (Shah, 2004). It means purity is the major concept used to confine womens' sexuality in Hindu tradition. The concept of impurity during menstrual periods has been institutionalized in Nepali Hindu society which is locally called mahinabari bhayeko or na chhune, untouchable (Bennett, 2002, p. 215). For institutionalizing this, polluted image of women is much discussed and brought into practice in Hindu society. However, most people may not be aware that women are restricted even to see the goddess inside the worship rooms of the Hindu households. Moreover, women are also excluded from certain auspicious days like Durga Puja (Thapa, 2010).

Similarly, Ramayan, a Sanskrit epic poem ascribed to the Hindu sage depicts the duties of relationships, portraying ideal characters like the ideal father, the ideal servant, the ideal brother, the ideal wife, and the ideal king. It conforms women's behavior to the brahmanic projection of the way things should be married lady suppose to be protected by 


\section{3| Manju Sharma}

her husband. Hinduism places great value on pre-marital chastity and this has significantly influenced practices. Girls were betrothed and married at a very young age. In married life, the wife's roles were centered at the home and she was not burdened with contributing towards the family income. A widow should be protected by the son. The death of her husband is a crisis for every Hindu wife, and marks her entrance into the third stage of life. Mitter (1991) giving Sudir Kakar's reference states that "very early in childhood, girls learn to accurately perceive and conform to the patriarchal images of femininity entertained by the men around them in the household." The Sita ideal is part of a Hindu woman's psychic inheritance, and she inculcates it, both overtly and unwittingly, in her daughters. Not only does a girl learn to bear cheerfully and without complaint all kinds of discomfort, injustice, and misfortune, but she also convinces that she should not disregard and criticize men's desire. As a wife, the Hindu woman is expected to live up as an image of the Stri Dharma, duties of a good wife. According to Stri Dharma, a wife should regard her husband as a god. She should serve him, follow him, pray for his well being. She shares his karma and his destiny, for this reason she sometimes should fast and go on pilgrimages to ensure her husbands' long life and success. If he dies prematurely, it was often regarded as her responsibility, her bad karma. These Hindu religious codes and principles were the bases to form the way of life, however, they might have their contextual meanings and might not universally applicable.

\section{Changing Scenario}

With influence of media, outer exposures, social movement and migration, the Hindu traditions on women are gradually redefined and reconstructed. Despite the low standing of women and despite the supremacy of authoritative Holy Scripture emphasizing the significance of women's submissiveness, women have a considerable historical legacy of empowerment in the Hindu tradition. The Interim Constitution 2007 and Eleventh Interim Plan (2007-2010) identified more pertinently that women, Dalits, Adibasi/Janajatis, Madhesis, Muslims, third gender, persons with differently able, and people living in geographically remote areas are excluded 


\section{4| Manju Sharma}

groups and focused on addressing the deep-rooted and systemic discrimination and exclusion. Thirteenth Plan (2013-2015) has also continued the positive discrimination to reduce the disparities in the society of the previous plan. This approach believes to attain economic, social and cultural inclusion by protecting and promoting the political, economic, social, human and cultural rights of excluded communities. The census data 2011 reveals that women's literacy rate has increased from 43 percent in 2001 to 58 percent in 2011. Life expectancy of women has increased to 69.6 years, higher than men, 67.9 years. Women have engaged in self employment activities and unpaid family labor is very high (64 percent of females in total). Female headed household has been increased. Allocation and implementation of the gender responsive budget (GRB) has been implemented in governmental organization (CBS, 2011). Abortion is legalized in Nepal in 2002 as safe choice for women to end unintended pregnancy. Female international migration has increased (12.4 percent in 2011). Among them 45 percent female migrants have moved to another country for job opportunities compared to 35 percent in 2001.

The changes in the society due to globalization can be clearly seen in economic, cultural, and political spheres. Open trade and spread of information and communication technologies have expanded economic opportunities, the demand of women in the banking, marketing, and foreign employment sectors has been increasing. And most importantly, women have plucked up courage to step forward and have taken prominent positions in the professions, business, and government. Gazetted level women administrator has been increased from 54 in 1981 to 790 in 2013. The proportion of women in the finance and business category has increased from 10 in 1981 to 31.3 percent in 2011 (population monograph, 2011). Moreover, most of them are now working to broaden the horizons even more so as to facilitate the ordinary community of the society. These economic opportunities where the women also make money have been empowering them in one or another way. The concept, "women are good Griha Laxmis (housewives)" has changed with the flow of female in the labor market, substantial participation in social activities and politics. Acharya \& Bennett's (1983) empirical 


\section{5| Manju Sharma}

study on women's profession and empowerment shows that the trend has shifted from household sector to market economy sector which increases their status (defined in terms of household decision making), while confinement to nonmarket subsistence production and domestic work reduces women's status. These changes have been seen across all countries, but female employment in the manufacturing and services have grown faster in global South than the global North.

With changing status and pattern in their daily life, the way of celebrating traditional feasts and festivals are also changing. The Hindu women in cities now celebrate both Hindu Teej and Christian Valentine day. Hindu festival Teej is celebrated by fasting whole day wishing husband's health and longer life by married women and wishing good future husband by unmarried girls. Similarly, Christian Valentine day now localized in Nepali as Pranaya Diwas is celebrated as a symbol of love and affection between intimate companions as well as married couple. Married couples do wish for longer congenial life and exchange gift each other. School and college students in urban area are becoming quite familiar with Valentine day. Many modern lyrists and celebrities' express in social media that they proposed their life partner in a Valentine day. This is conveying and manifesting in a way that the day is 'good luck' for proposal in a way or another.

Similarly, having a boyfriend which previously was consider as a crime, is now acceptable at least in city parents. I have met many unmarried young couple coming at working place to meet one another's parent for official help on abroad educational documentation for example property evaluation, attestation of education certificates and other administrative services.

Inter-caste marriage was taken as a great mistake and those couple were boycotted by a society as a result they had have to leave a community in the past. One of the grandmothers, Laxmi (changed name) aged 72, Brahmin, literate lived in elder house in Kathmandu told her story that she exiled from her house at the age of 20 just because of she went to meet her relative in India with a male neighbor 


\section{6| Manju Sharma}

without taking permission. Another grandmother, Kamala (changed name), aged 75, Chettri, illiterate but could tell many puranic stories told that she exiled at the age of 22 only in a suspension of love affair with a servant of lower caste. Another mother, Sita (changed name), aged 70, Chettri told her story that she escaped from the house because she became pregnant with a lower caste man. Now it is started to say it is okey to have a inter caste marriage if there is love affair between a girl and a boy. My mother used to say to my father on my brother's bride searching time that "it is not a love marriage to go to the lower caste in the name of qualified girl". It indicates that inter caste marriage with lower caste is acceptable in love marriage. Moreover, 'living together' culture; a western way of life can be seen in the capital city. Though there is no study on such couples, report of National Women's Commission shows considerable numbers are living together in Kathmandu without marriage. Many of such couples don't tell their parents about cohabitation and pose themselves as married couple in the locality they live in (Nepali Times 11-17 July 2014).

The era of globalization has accelerated the pace of migration in the last 15 years. The trend of outsourcing and supply of cheap labour mainly from Asian labour market to advanced countries like America, Europe, South Korea and Australia has been increased. Subedi's empirical figure that done in 2011 shows that in compare to male migration women's migration has increased in developed country and more for skilled jobs. Similarly out of total female migration, 47 percent are for job and 15 percent are for higher study. Comparatively far larger proportions of female have made Europe, Americas, other countries and the Pacific as their destination than that of male. One out of five female has gone to West Asia while the corresponding proportion is two out of every five among male (Subedi, 2011).

The increasing cost of living, privatization of services, demanding quality of life and consumerism are a few factors that have created a forced situation for urban couples to make more money. Along with more career oriented opportunities for women in 'dynamic' 'globalized' economy there is also a compulsion for couples to earn 


\section{7| Manju Sharma}

together to manage household across various strata of society.

Similarly, the changes unleashed by globalization-especially the greater access to economic opportunities and information among women-is also influencing existing gender roles and norms. Now, even in a rural area, women have mobile set at least to those whose husbands are in abroad. Remittances play significant role in Nepalese economy as well as women's way of life. They might take information from their husband daily or every alternative day.

The development of media technology has blurred the boundary between the private and the public by providing new opportunities for self-expression and communication. New social networking sites have made wider virtual communities for Nepalese girls/women. There are many social sites available, among them facebook is the most popular in all age groups. Most of the college girls are concerned about likes and comments got in the uploaded picture on face-book. It has become a means of individual's judgment by counting likes and comments. In the other hand, women are considered modernized who are active in social net like face book and twitter, the given comments on uploaded facebook show that Nepali people want to see the woman in a way that the Hindu tradition portrayed for her. It is found from the empirical study that a girl gets more 'likes' and positive comments if she uploads a picture with traditional dress than a modern sleeveless shirt. A person by keeping the world in hand (using high tech mobile set with number of apps) comments 'this is not for you' if a female columnist uploads a picture wearing half pant. Facebook has become most effective social media. It has not only established as a means of communication and updating individual status but also one of the effective means of searching life partner. People who use public transportation enjoy lok dohori (duet folk songs) made on facebook. Most of them depict love affairs through facebook.

Further, in a micro level, globalization unleashes the household chores. When both wife and husband have to work, it demands share of household chores, take part in baby and elder care and other social obligations which previously suppose to perform by the women. 


\section{8| Manju Sharma}

When women turned into income earners they likely are able to influence their new position from silent recipient to active decision maker on use of household income among household members. This empowerment leads to formulate women organization like Aama Samuha (Mother's Group) to fight against the bad practices and injustices on the women like domestic violence, alcoholism, and abuses.

Similarly, unleashed globalization has supported women movements through which the bad cultural practices towards women became abolished. Women movements have been arisen against bad practices on widow, girl/women trafficking, chhaupadi partha (system where girls and women are isolated from family and home during several days in their menstrual cycle), and Deuki Partha (system where young girl is offered to the local Hindu temple to gain religious merit). These movements have become successful to change social norms and values on widow and menstruation. Widow was not supposed to be beautiful, therefore they had have to leave to do make up, leave to wear attractive color, and leave to laugh openly. Menstruation is also taken as an impurity and girls/women have not supposed to mixing up with other family members, elders and specially men. Chhaupadi custom depicts a practice of menstruated women. It is a tradition where women are segregated and kept away from home avoiding daily activities during the menstruation period believing "impure" and fear of "ritual pollution". This practice can be seen all over the country in one or another way but it is mostly prevalent in the far-western region and the degree and influence of this practice is relatively higher in so called upper caste as compared to the lower caste people of the Hindu family. At the time of menstruation a girl is not suppose to worship God, to cook food, to touch male, to read holy book. If she does knowingly or unknowingly "misfortunes" may happen. Similarly, Deuki and Jhuma Partha is a tradition where girls are offered to deities as a sacrifice to fulfill their wishes for health recovery, bearing son, and other accomplishments. The offered girls are required to spend their time in caring for the temple and live on whatever cash and kind is obtained as puja offering from worshippers. They are restricted to marry. At the same time some make wish for sexual relation with them for religious and spiritual 


\section{9| Manju Sharma}

sanctity.

After women movement, government of Nepal has taken positive initiatives applying positive discrimination approach in education, health, and public service. Interventions are taken in policy as well as action level. Similarly, women now enjoy established property right, political right, and abortion right. Government of Nepal has also taken positive discrimination approach from capacity buildings activities to decision making level to upgrade women's status. Similarly, there are reserved seat in army, police, political systems and most of the organs of a nation state. Many women activists are active to remove unfair legal provisions in policy level.

Further, after the Government of Nepal opened up foreign employment for women, women migration for foreign employment has become more common since the last decade. Previously the work for foreign employment was beyond the imagination for women. Most of the Nepali migrant women workers are engaged in household works like cooking, cleaning, and nurturing. They do experience a particular culture in the closest way. They do not only learn the particular culture of food, norms and values of a society and roles and responsibility of a family member but also reflect these practices in their own lives.

\section{Impact}

There is a debate in literature on the impact of globalization in Nepalese women. Both types of notion, positive and negative can be found though there is a very few academic literature on it.

Though the globalization process does not make any biasness among the class and gender; the intensity of its impact could differ on the basis of existing class differences and norms and values of a gender. In the case of Nepalese society, there are many strata of class. Higher class and richer people certainly have higher access to global opportunities as compare to lower class. Similarly, there are many disparaging beliefs that reflecting the negative attitude towards girl/woman could impact negatively by the globalization 
process. Malla (2001) has listed some more gendered metaphors for example Dhilo paye, Chhora paye (Let it be late, but let it be a son); Chhora paye swarga jaane (The birth of a son paves the way to heaven); Chhori ko janma hare ko karma (A daughter is born with a doomed fate); Chhora paye khasi, Chhori paye Pharsi (If a son is born, it is celebrated by sacrificing a goat, if it's daughter, a pumpkin is enough); Chhora bhaye sansar ujyalo, Chhori bhaye bhanchha ujyalo (Son brightens the whole world, whereas a daughter brightens only the kitchen); Kanya Daan (a daughter should be given away as a gift); Mare paap, pale punya (It's a sin if the groom kills the bride, charity if nurtured); Srimati bhaneko paitalako dhulo ho (Wife is the dust of the foot); Chhori mari, thulo ghar pari (If a daughter dies, we can say she has been married into a rich home); Pothi base ghar mahscha (A woman ruled house is sure to be destroyed); and Swasni mancheko buddhi pachhadi (Women are always shortsighted). These types of beliefs discourage girls and encourage violence in one or another way.

\section{Positive Impact}

Economically Nepalese women are becoming more active. Nord's study on trade effects on women shows that women's share of the labour force has increased over time and the wage gap between men and women has been narrowed. Trade liberalization is likely to create jobs for women and over time increase their relative wages (Nord, 2003).Globalization has increased dimension of women's employment and dimension of globalization have empowered the women. Population Monograph (2011) shows that women's occupation has shifted from agriculture to non-agriculture. It shows positive impact of globalization on productivity. The decisionmaking power of women is linked to women's employment and income, which in turn is a critical element of the crusade against poverty and illiteracy.

The employment opportunities that the globalization offers have empowered the women-employment opportunities are increasing. Globalization has given a power they lacked in the past - power to end the system that breeds poverty, exploitation and oppression to 


\section{1| Manju Sharma}

some extent to the elite group where they chose the management and other professional. It prospects the higher quality of education, at least on those who can afford economically and financially. The negative attitude towards women is changing towards positive. It can be found more egalitarian set of gender relationship. World development report shows that the trend is towards reduction in gender inequalities. New information and communications technology have improved the access of women to micro credit, employment opportunities and information in general (Global Development Report, 2008).

Globalization has also unleashed I/NGOs. The establishment of various NGOs and the collaborative efforts of these organizations have improved the lives of women in developing nations like Nepal. Representatives from NGOs agreed that global feminism should be established to reduce the inequality facing women in these nations and to improve the advancement of women in society. NGOs have reached out to the women to meet their needs in farming, environmental protection, healthcare, domestic issues, employment conditions, and to reduce the financial strains in their everyday lives including income generation livelihood.

Similarly, the collective organization of women's groups has been increased and they have generated the attention of the media. Now we can see the women column and columnist in almost all national level papers. Now issues of women are discussed very often in BBC Nepali sewa, Radio Nepal and almost all TV channels which is necessary in educating the general public. The continued efforts of these groups and the economic realization of the importance women's work will eventually create greater social awareness about the inequalities facing women in the nation.

\section{Negative Impact}

It is experienced that Nepali women are becoming more self-reliant, empowered and independent in one hand and in the same time daily news shows that they are suffering from the increasing rate of girl trafficking, prostitutions, domestic violence, rape cases, and sexual 
abuse. Similarly, the cases of assignations, suicide, and violence associated with sex have been increasing.

Although technology replacing women in agriculture to industry, the working condition, security and safety net are not proper and gender friendly. Women columns in national as well as local news papers mostly state that the women are engaged in contractual, irregular and unstable works and unhealthy working condition in abroad. There is no child care, community care, and social security provision in the job. Further, the women are being sold as a sex slaves mostly in India and Middle East. They are working as domestic workers or bar attendants.

Similarly, global consumerist culture is systematically converting wants into needs. The habits tend to go fulfilling needs without working. This pushes simple society to consumerist therefore the investment trend is weaker; most of the remittance is used in consumption. It impacts negatively in the governmental agenda of gender equality in one hand and social and economic exploitation for the masses of vulnerable, poor and docile female labour force in a developing country (Dogra, N 2008) like Nepal in the other hand.

Similarly, although globalization has unleashed economic accessibility to the women, the self respect and dignity of the work remain questionable. Desai's empirical study on developing countries shows that it has reduced the ability of women to find paid work that offers security and dignity (Desai 2002). Now, women are becoming the breadwinners in most households because of the lack of male responsibility. Because of male migration, the women have to bear triple loads: caring, farming, and paid employment in the rural sector. Young daughters are financially supporting their parents and fellow siblings, while mothers (married or single) are seeking informal work to provide for their children. The situation made the women to break down the norms which previously suppose not to do for example ploughing and other outer works.

Further, although women are economically active, female labor is not rewarded in relation to the impact they have on the society. 


\section{3| Manju Sharma}

Therefore, women's work continues to be stigmatized as inferior, in comparison to males work, regardless of their increased responsibilities in society. Bacchus (2003) views that the economic policies associated with globalization create the most negative impact on women in the developing world. He suggests economists and policy makers to consider the impact on women's lives and the inequalities that exist between men and women. Enabling the advancement of female opportunities and guaranteeing female workers, more rights will increase the quality of life and create a more sustainable living standard for women in the developing world.

\section{Conclusion}

The main objective of the study was to examine the impact on the way of life of Nepalese women due to globalization. After introducing the some theoretically foundation about the way of life, Hinduism, and culture, this paper has highlighted the Hindu tradition and traditionally expected roles and responsibilities of the Hindu woman. Based on the academic literature and authentic websites it is found that globalization process has affected almost all aspects of the women's way of life. Globalization has opened up economic opportunities to the women; now women are not only employed in the local market but also in the global market. Globalization process has empowered the women. Due to women movements many bad social and cultural practices have been abolished. Government of Nepal has adapted many positive actions to uplift women's status in the society. Now many social norms and values of Hindu society towards the women have been changed and expected roles and responsibilities are shifted.

Social networking sites are not only remained as the space of public sharing but also have established as an effective means of private sharing. Open media has increased consumerism. This is leading to make more money that could lead towards risky job. The migration has given outer exposures, uplifted economic status, and made self reliant. Simultaneously, the dignity and security of the job are questionable. As psycho-social cost of migration for example family loneliness, anxiety, divorce, and family separation are not accounted 


\section{4| Manju Sharma}

there is need to make scientific research on psyco-social effects of migration in both migrated and live in home country.

\section{Reference}

Acharya M; Bennett, L. (1983). Women and the subsistence sector. Economic participation and household decision making in Nepal. Washington, D.C., World Bank, 1983 Jan. 140 p. (World Bank Staff Working Papers No. 526).

Bacchus N. (2005). The Effects of Globalization on Women in Developing Nations. Pace University.

Bairoch, P. (2000). The Constituent Economic Principles of globalization in Historical Perspective: Myths and Realities. International Sociology. SAGE. 197-214.

Bauman, Z. (1998). Globalization. The Human Consequences of Globalization. Minneapolis: University of Minnesota Press. Bennett, L. (2002).Dangerous wives and sacred sisters: Social and symbolic roles of high-caste women in Nepal. Kathmandu: Mandala Publications.

Berger, P. L. and Luckmann, T. (1966). The Social Construction of Reality: A Treatise in the Sociology of Knowledge. Garden City, NY: Anchor Books.

Bourdieu, P. and Wacquant L.J.D. (1992). An Invitation to Reflexive Sociology. Chicago Press.

Castells, M. (2009). Communication Power. New York: Oxford University Press.

(1997). The Power of Identity. Oxford: Blackwell.

CBS (2011). Population monograph. Kathmandu, Central Bureau of Statistics, His Majesty's Government of Nepal.

Chawala, J. (1992). The mythic origins of the menstrual taboo in the Rig Veda. Retrieved from http://www.matrika-india.org/ Research/MythicOrigins.html

Democracy Nepal: Property Right of Nepalese Women, Sapana Malla.http://www.nepaldemocracy.org/gender/property rights.htm. Accessed 22 Nov, 2014.

Dogra N., The Impact of Globalization on Women. http:// www.wscpedia.org/index.php?option =com content\&view=article\&id=41:the-impact-of-globalization- 
on-women. Accessed Nov 24, 3014.

Eleventh Three Years Interim Plan (2007-2010).

El-Ojeili, C. and Hayden, P. (2006). Critical Theories of Globalization. Basingstoke: Palgrave Macmillan.

Fisher, J.F. (2011). Globalization in Nepal, Theory and Practice. The Mahech Chandra Regmi Lecture. Social Science Baha, Himal Books.

Gergen, Kenneth.J. (2003). 'Knowledge as Socially constructed' in Mary Gergen. and Kenneth J. Gergen (eds). Social Construction A Reader. London: SAGE Publication.

Gewali, S. B. (Ed.). (1954). Bhanubhakta ko Ramayana [The Ramayana of Bhanubhakta]. Kathmandu: Pasupat Yantralaya.

Kautilya, ........Chanakya Niti Darpan.http://www.goodreads.com/ book/show/389677. Chanakya_s_Niti_Darpan. Retrived 10 July, 2015.

Halder, D., \& Jaishankar, K. (2009).Property rights of Hindu women: A feminist review of succession laws of ancient, medieval, and modern India.Journal of Law and Religion, 24(2), 663-687.

Held, D., and McGrew, A. (eds) (2000). The Great Globalization Debate: An Introduction The Global Transformation Reader. Polity.

Hiebert, PaulG.(2008). Transforming Worldviews AnAnthropological Understanding of how People Change. Michigan: Barker Academic, a division of Barker Publishing Group.

Hiebert, Paul G. (1985). Anthropological Insights for Missionaries. Michigan:Baker Book House.

Inda, J. X. and Rosaldo, R. (eds.) (2002). A world in Motion. The Anthropology of Globalalization: a Reader. Blackwell.

Malla, S. (2001). Property right of Nepalese women. Kathmandu: Friedrich Ebert Stiftung, Nepal. Retrieved from http://www. nepaldemocracy.org/gender/property_rights, 2072.03.24.

Mitter, S. S. (1991). Dharma's Daughter: Contemporary Indian women and Hindu Culture. Rutgers University Press.

Nepali Times 11-17 July 2014, http://nepalitimes.com/article/nation/ women-in-live-in-relationships-more-vulnerable, 1514.

Nord S. K.,(2003). The Impact of Trade Liberalization on Women's 
Job Opportunities and Earnings in Developing Countries. World Trade Review, Vol 2, issue 2 Pp 221-231.

Shah, S. (2004). A project of memoreality: Transnational development and local activism among rural women in Nepal (Unpublished doctoral thesis). Harvard University, Cambridge, USA.

South Asian Studies A Research Journal of South Asian Studies Vol. 24, No.2, July-December 2009, pp. 242-249.

Subedi, B. (2015).The Dynamics of Migration in Nepal. Presented in NNAA, February 20, 2015, Kathmandu Nepal.

Thapa, A. (2010, October 08). Theduality that is Durga. ekantipur. Retrieved from http:/www.ekantipur.com/the-kathmandupost/2010/10/08/features/the-duality-that-is-durga/213672/. The Interim Constitution of Nepal, 2007.

The Laws of Manu. New Delhi, Volume 5, page 147-65.

Thirteenth Three Years Plan (2013-2016).

The Contemporary Hindu Women of India: An Overview Tahira Basharat University of the Punjab, Lahore.

The Laws of Manu, 1500 BC. Translated by Buhler. http:// sanskritdocuments.org/all pdf/manusmriti.pdf Retrived in 23 July, 2015.

The Three Years Thirteenth Plan (2013-2016).

Tylor, E.B. (1871) from Wikimedia Commons, Popular Science Monthly 26 (1884): 145.

UNCTAD, Government of Inida, Impact of Trade and Globalization on Women Workers in the Handicraft Sector: Evidence from the Carpet and Embroidery Sectors, STADD.

Young, K. K. (2002). Women and Hinduism. In A. Sharma (Ed.), Women in Indian religions (pp. 3-37). New Delhi: Oxford University Press. 